\title{
Smart Teacher Smart Class Portal in Enhancing Secondary School English Teachers' English Language Teaching Knowledge in Bangladesh
}

\author{
SM Kamruddin Ropum and Md. Yasin Arafat
}

\begin{abstract}
Smart teacher smart class (STSC) is a portal developed by Dnet which contains curriculum, teachers' guide, education policy, textbook, lesson plan, multimedia contents, and teaching-learning strategies on different subjects aiming to provide content and pedagogical support to the secondary school teachers in Bangladesh. Making an offline CD, the STSC portal is provided to the respective teachers of secondary schools Dnet works with. The regular use of the STSC portal helps the teachers to improve their knowledge about effective teaching-learning techniques. The study was designed as one group pre-test post-test quasi-experimental method to find the effect of STSC portal on secondary school English teachers' English language teaching knowledge (ELTK). Twenty eight English teachers from 14 secondary schools were selected purposively to form the group and the tests were administered on them considering 6 months intervention (STSC portal) period. The test was adapted from Cambridge language teaching knowledge (TKT) test focusing on different ELT aspects. The tests scores of the teachers were categorized in 4 knowledge levels: limited, basic, deep and extensive. The findings of the study show that the STSC portal induces a significant improvement of the teachers' ELTK. Most of the teachers showed better performances in the post-test than the pre-test. Moreover, significance (0.001) and effect size score (0.91) also depict a clear and large effect in enhancing teachers' ELTK.
\end{abstract}

Keywords: English Language Teaching, English Language Teaching Knowledge, Teaching Knowledge Test, Multimedia Content, Smart Class Room, Professional Development

\section{Introduction}

Quality in education has been being emphasized for several decades by educationists and policy makers in the world. In addition to emphasizing the need to achieve Education for All (EFA), The World Education Forum in Dakar in 2000 noticed the need to improve the quality of education as well by recommending "Improve all aspects of the quality of education to achieve recognized and measurable learning outcomes for all especially in literacy, numeracy and essential life skills." (Dakar Framework for Action, Article 7, World Education Forum, 2000). Likewise, Delors et al. (1996), in the report 'Learning: the Treasure Within' for the UNESCO's International Commission on Education for the Twenty-first Century, concluded that "... a greater focus on quality is desirable everywhere, even in countries 
where all children are enrolled in basic education". In general, quality education is an education that provides students with the skills to deal with and seek solutions to the challenges confronting mankind (Fredriksson, 2004).

The continuous global efforts have led to improvements in many aspects of education, particularly in increasing enrollment and literacy rate, decreasing drop-outs and reducing gender differences in education opportunities. The number of children enrolled in pre-primary schools grew by almost 60 million over the period (UNESCO, 2014). But, what about the quality? Many countries, like Bangladesh, are struggling to improve the quality of their education systems. Researchers and educationists claim that quality teacher is a necessity for ensuring better quality in education. It is pragmatically evident that the teacher is one of the most influencing agents in order to ensure and improve the quality of education. Mourshed, Chijioke, and Barber (2007) proclaimed that the quality of an education system cannot exceed the quality of its teachers. Mackay (2012) believed that the quality teaching is the leading in-school influence on student outcomes, with quality school leadership. Goodwin (2008) also considered the quality of teacher as one of the most important factors for shaping the learning and growth of students. However, in Bangladesh, teacher's quality is always questionable. Very few of the teachers are able to make the classroom environment enjoyable. Several research studies showed that the way Bangladeshi teachers conduct lessons, especially English and science, is less interesting. Most of the time teachers are unable to ensure sustainable learning of the students. The teachers do not use proper instructional strategies to make students learn any lesson in the classroom (Mullik \& Sheesh, 2008). Lecturing and reading out from the textbook with occasional explanation of the text are the dominant methods used in the classroom for lesson demonstration (Ahmed et al, 2005). Haq (2006) also argued that the teachers, basically, follow the conventional teaching method and they discourage students to ask questions. No effective formative assessment is evident in classrooms due to the lack of teachers' knowledge about the classroom assessment.

The Government of Bangladesh (GoB) also acknowledges that the traditional teachinglearning process is teacher-centric which provides very little opportunities for students to get engaged in the learning process (Prime Minister's Office, 2013). To improve the situation, the GoB has taken several initiatives. Among them, integration of ICT in education in order to help teachers to conduct effective lessons and ensuring sustainable learning of students is the mentionable one. Besides the government's initiatives, a number of development organizations, like Dnet, are innovating and implementing different models for incorporating ICT in education in Bangladesh. Dnet, a social enterprise established in 2001, always tries to integrate ICT in any of their initiatives for providing its' beneficiaries with the optimum benefits. Likewise, integration of ICT in education for creating a sustainable learning environment in the schools and for empowering teachers is one of the major targets of Dnet. As an attempt of ICT integration in classroom teaching-learning process, Dnet developed a portal titled 'Smart Teacher Smart Class (STSC)' for the teachers of secondary schools in Bangladesh in 2013.

\section{Dnet}

Dnet was established in 2001 as a not-forprofit social enterprise, with a vision for a society where information and knowledge facilitates all stakeholders' participation in generation of wealth and its equitable 
distribution for poverty alleviation. Dnet pioneered in research on using ICT as a primary means for alleviating poverty, empowerment through minimizing the digital divide and access to information, civic participation, capacity development and employment generation (Dnet, 2014). Education is one of the key working themes of Dnet. Under this theme, Dnet took a number of initiatives for educational development, for instance, Computer Learning Program, Smart Classroom, AfterSchool Club etc. In almost all of the initiatives, Dnet integrated ICT in order to get the fullest benefit.

The educational initiatives of Dnet includes, basically, a 3-pronged target to be achieved. Firstly, it attempts to empower teachers through providing them with basic ICT skills for developing digital materials for their lessons and training on effective use of ICT in the classroom. Since the teachers are more enabled, they feel themselves more confident and empowered. Secondly, Dnet tries to create equal learning opportunities in schools by proving schools with different ICT devices, like, computer, television, internet dongle etc. The ICT devices make the classroom environment enjoyable and learners get stimulated to participate in the lesson. Finally, it targets to ensure sustainable learning of the students through digitizing the hard-to-grasp contents of textbooks and providing them to schools.

\section{Smart Teacher Smart Class (STSC) portal}

As a result of its continuous effort to integrate ICT in education, Dnet developed Smart Teacher Smart Class (STSC) portal in 2013. Dnet prepared a number of multimedia contents based on the textbooks of secondary level in Bangladesh. For multimedia content development, Dnet chose 4 subjects, English, Mathematics, Science and
Geography, of secondary level considering them more difficult for Bangladeshi students than the other subjects. Through a rigorous process, Dnet selected different topics / concepts from the textbooks which seemed complex and hard to grasp to the learners. To finalize the topics, Dnet took feedback and opinions from respective teachers, students, subject specialists and curriculum specialists. The types of the multimedia contents vary depending on the nature of the selected topics. The common types are video, audio, animation, game, power point slides etc. Going through various reviews and tryouts, the contents got finalized. In addition to developing multimedia contents, Dnet collected contents from other organizations working in the same area in Bangladesh. Moreover, Dnet developed digital materials (E-book) on modern teaching-learning approaches, subject specific instructions for teachers, lesson plans for different lessons of aforementioned subjects, and collected soft copies of teacher's guides, textbooks, curriculums, education policies and reference books. Comprising all the developed and collected materials, Dnet made an offline CD. This CD is called 'STSC Portal'.

On the other hand, Dnet established a number of Smart Classrooms in secondary schools throughout Bangladesh. Smart Classroom (SCR) is not setting up a new classroom in a school, rather equipping an existing classroom with various ICT devices such as laptop, television, modem and other supporting devices like solar panel and cables. Partnering with different donors and organizations, Dnet established 150 SCRs in 150 different secondary schools (named as SCR schools) in diverse geographical locations in Bangladesh. These SCR schools have necessary equipment and infrastructure for using the STSC portal. Therefore, Dnet provided each of these schools with a copy of STSC portal and respective subject teachers of the schools with training for effective use 
of the portal in classroom. Moreover, Dnet gave an orientation of STSC portal to all of the teachers of SCR schools through physical visits to each school. The teachers used the multimedia contents in the respective lessons and the other materials of the portal for the preparation of lesson conduction.

Through the STSC portal, not only integration of ICT in education is ensured, but also there is a scope for the teachers to improve their pedagogical knowledge as well as understanding of modern teachinglearning strategies. As discussed earlier, poor teaching-learning strategies may lead to improper learning of the students. Teachers' empowerment and development are inevitable for ensuring proper and sustainable learning of the student. Mukti (2002) found a positive relationship in her study between teacher empowerment and the schools' climate and effectiveness which are directly related to students' achievement. Teacher empowerment is not always indicative to increase their remuneration, give them space to address their own thinking. It is related to their knowledge, skills and availability of resources. Developing teachers' knowledge and ability increases teachers' empowerment. Developing teachers' creativity, confidence, collaboration, motivation is the force for enhancing teaching knowledge and teachers' empowerment. Availability of better equipment and materials, increase teachers' knowledge, skills and confidence and to feel them empowered (Romanish 1993). The STSC portal may have those equipment and materials which increases teachers' knowledge and skills and consequently make them empowered. Besides Dnet, some other organizations in Bangladesh are working to integrate ICT in education. However, most of them develop multimedia contents and distribute them among schools with training. But, due to the lack of necessary pedagogical knowledge and skills, most of the time teachers do not bring them in their lessons. In contrast, Dnet combined all the necessary materials for teachers' development in one portal in an organized way.

The STSC portal includes the subject 'English' along with the other 3 subjects as stated above. The modern and effective strategies for teaching English, lesson plans for each English lesson, English textbooks and multimedia contents developed based on English textbooks were in the portal. Furthermore, the English teachers were provided training for using the portal and bringing their learning in their lessons. The regular use of the STSC portal was supposed to help the English teachers to improve their English language teaching knowledge and accordingly develop their skills of English lesson conduction. However, the study mainly deals with the English teachers' English language teaching knowledge. Through this study, the effect of the STSC portal in improving English teachers' knowledge about English language teaching has been explored.

\section{Objectives}

The general objective of the study was to analyze the effect of STSC portal in enhancing secondary school English teachers' ELT knowledge in Bangladesh. The specific objectives of the study were to:

i) identify the level of ELTK of secondary school English teachers before and after the intervention period of STSC portal; and

ii) examine the relationship between the STSC portal and changes of the levels of ELTK of secondary school English teachers.

\section{Methodology}

According to Cambridge ESOL (2007), English teachers' English language 
teaching knowledge (ELTK) is positively related to their performance in English lessons. The STSC portal of Dnet contains a lot of materials related to English language teaching, which can enhance secondary school English teachers' English language teaching knowledge. This study identifies mainly the impact of the STSC portal on secondary school English teachers' ELTK knowledge. Nunan (1992) explained that the experimental design can be ideal in conducting research in the area of language teaching-learning, where strength of the relationship among variables is needed to explore, especially to identify the effectiveness of any intervention. In the present study, STSC portal can be considered as independent variable (intervention) and secondary school teachers' English language teaching knowledge can be considered as dependent variable. At this point, an experimental study can be designed to identify the relationship between these two variables. However, true experimental design is difficult in the research related to humans where it is almost impossible to control many extraneous variables. That is why, to identify the impact of STSC portal on secondary school teachers' English language teaching knowledge, one group quasi-experimental design was applied in the present study. Pretest and post-test were administered on the group. Between the tests, the STSC portal was provided to the teachers as intervention through an offline CD.

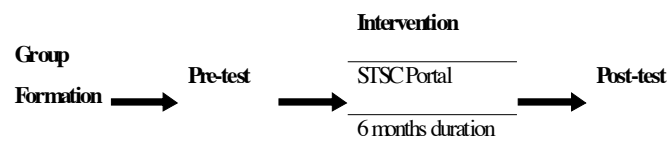

Figure 1: Research design

\section{Sample and sampling technique}

Firstly, 14 schools were selected purposively from the 150 SCR schools. After that, 28 teachers from these schools ( 2 from each school) were selected purposefully. Then, the English teachers' knowledge of ELT was assessed before providing the CD through a test. Six months were given as the intervention period and after that, they were assessed again.

Table 1: Overview of the sample and sampling technique

\begin{tabular}{ccll}
\hline Respondents & $\begin{array}{c}\text { Number of } \\
\text { respondents }\end{array}$ & \multicolumn{1}{c}{ Purpose } & $\begin{array}{c}\text { Selection } \\
\text { technique }\end{array}$ \\
\hline English teachers & 28 & Participating in ELTKtest & Purposive \\
\hline English teachers & 28 & $\begin{array}{l}\text { Participating in in-depth } \\
\text { interview }\end{array}$ & Same teacher \\
\hline
\end{tabular}

\section{Data collection method}

Two data collection methods were used in this study. English Language Teaching Knowledge (ELTK) test was conducted for assessing the English teachers' level of knowledge necessary for conducting effective lessons of English language. Moreover, in-depth interviews were conducted mainly to know how the portal made changes among teachers.

\section{ELTK test}

The test was adapted from the Cambridge language teaching knowledge (TKT) test (Cambridge ESOL, 2007, module 1, 2 \& 3). The test contains 100 items, each of which carried 1 mark. Teachers got one (1) mark for every right answer and zero (0) for every wrong answer. No fractional marking and negative marking system was there. The test items mainly covered the English language issues, English language skills and sub skills, grammar, lexis, phonology, functions, English language learning and 
teaching, ELT methodologies, lesson planning, use of resources, motivation, assessment, error correction, learners characteristics, learners needs, managing teaching learning processes, classroom examples and experiences, etc. Types of the items were basically multiple-choice questions, fill in the gaps, matching, truefalse, option matching, odd one out, etc. and 100 minutes were allocated to answer all the items.

\section{In-depth interviews}

In addition to the English language knowledge test, an in-depth interview was conducted with the sample teachers after the intervention period. The objective of the interview was to find out the reasons behind the changes of their ELTK and justify the relationship between the changes of their ELTK and the roles of the STSC portal. The interview contains five open-ended questions focusing on teachers' perception towards STSC portal, their experience in using the STSC portal, effect of STSC portal on their ELTK, their classroom practices and students' interactions. The responses of each question were captured by the interviewer in written format which were transcribed later. Most of the time, the interviewer prompted respondents to tell elaborately.For example, while the respondents were telling about their experience in using STSC portal, the interviewer prompted them to tell positive experiences as well as negatives.

The ELTK test and interview schedule were developed through piloting and validation by the ELT experts and conducted with proper permission from the samples and by maintaining research ethics.

\section{Data analysis}

At the end of the ELTK test, each teacher's right answers were calculated and the cumulative score (total right answers of a teacher) of the teacher was categorized in 4 knowledge levels: limited, basic, deep and extensive knowledge level. The four levels and respective scores have been shown below:

Table 2: ELTK levels

\begin{tabular}{|l|l|l|}
\hline Levels & Score & Level Title \\
\hline Level 1 & $50 \%$ and above & $\begin{array}{l}\text { Extensive } \\
\text { knowledgeable }\end{array}$ \\
\hline Level 2 & $35 \%-49 \%$ & $\begin{array}{l}\text { Deep } \\
\text { knowledgeable }\end{array}$ \\
\hline Level 3 & $20 \%-34 \%$ & $\begin{array}{l}\text { Basic } \\
\text { knowledgeable }\end{array}$ \\
\hline Level 4 & Below 20\% & $\begin{array}{l}\text { Limited } \\
\text { knowledgeable }\end{array}$ \\
\hline
\end{tabular}

The individual teacher's levels were analyzed and calculated through statistical analysis and calculation such as mean, standard deviation, t-test, significance and effect size calculation. The effect size was calculated by Cohen's d formula (Connolly, 2007). The effect size is just the standardized mean difference between the two groups. After calculating effect size, a score was found between zero (0) and one (1). The score was interpreted by five points scale (trivial, small, medium, large and very large effect) where lower score denotes lower effect and higher score denotes higher effect. Responses of the teachers from the interviews were analyzed thematically and used for supporting the quantitative part of the study.

\section{Findings}

The study revealed secondary school English teachers' ELTK in order to measure the effect of STSC portal in enhancing the teachers' ELTK in Bangladesh. The following findings were formed while exploring the above situation through analysis of the collected data. 


\section{ELTK level of secondary school English teachers in Bangladesh}

Through the ELTK level test, it was found in pre-test that most $(57.10 \%)$ of the participating secondary school teachers had basic knowledge of English language teaching. On the other hand, a significant number $(28.60 \%)$ of the teachers had limited knowledge on ELT where very few $(7.10 \%)$ of the teachers belonged in both deep knowledge and extensive knowledge level of ELTK. It may give the picture of the Bangladeshi secondary school English teachers' knowledge on ELT that they have restricted to basic knowledge of different areas of ELT such as English language learning and teaching, show familiarity with some of the concepts, terminology, practices and process which are related to language skills, factors in the language learning, methods, tasks, activities of the language teacher, and are able to relate existing knowledge to familiar classroom situations. However, very few of them had extensive knowledge on ELT such as familiarity with the full range of concepts, terminologies, practices and processes describing language skills. They also knew about the different ELT methodologies, tasks, activities and could relate knowledge to different classroom situations.

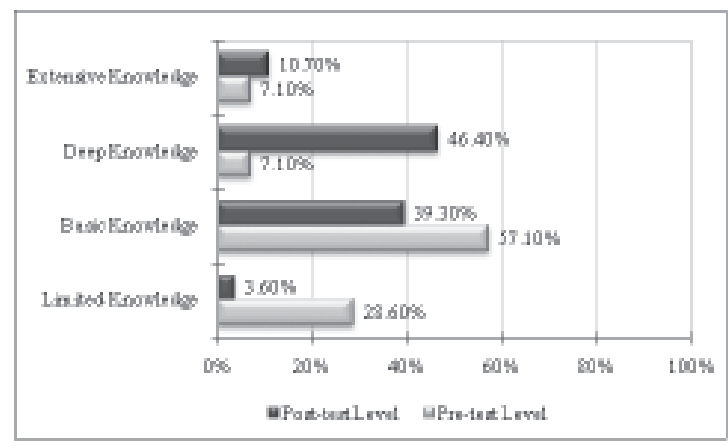

Figure 2: English teachers' ELTK in pre and post-test
On the other hand, after using the STSC portal, majority of the selected teachers gained upper level of ELTK. After post-test, it was found that $46.40 \%$ of the teachers' belonged in the level of deep knowledge where it was only $7.10 \%$ in pre-test. Significantly the number of teachers decreased from $28.60 \%$ to $3.60 \%$ in level of limited knowledge. Moreover, in level of basic knowledge, a low number (39.30\%) of teachers belonged after post-test. In addition, a few more teachers $(7.10 \%$ in pretest \& $10.70 \%$ in post-test) were found in the highest level (extensive knowledge level) after post-test. After using the STSC portal, the picture was changed and then most of the teachers showed better knowledge of ELT. They had deep knowledge on ELT where they demonstrated familiarity with the ELT concepts, terminologies, methodologies, practices and process as well as ability to relate knowledge to both familiar and unfamiliar classroom situations in majority cases.

\section{Effect of STSC Portal in Enhancing Teachers' ELTK}

Effect of smart teacher smart class portal on teachers' English language teaching was calculated through a statistical analysis such as mean, standard deviation, t-test, significance and effect size calculation.

It was found that the mean of teachers' level in the post-test was 2.64 where it was 1.93 in the pre-test. So, it indicates clear improvement of teachers' level on ELTK. On the other hand, standard deviation of teachers' performance in the pre-test was 0.813 which was found 0.731 in the posttest. It indicates closer performance of teachers in the post-test than the pre-test which is also significant. Moreover, in 95\% confidence level, between the pre-test and the post-test scores of the teachers, $t$ was calculated at 3.456 which was greater than the $t$ critical value (2.009). It shows that 
teachers' performance in pre-test and posttest was significantly different and the difference was found due to the positive effect of STSC portal.

On the other hand, according to Cohen's d formula, the significance value was found 0.001 at 0.05 level and the effect value was found 0.91, which shows STSC portal has significantly very large effect in enhancing participating Bangladeshi secondary school English teachers' ELT knowledge.
"The animated contents especially the games on different English lessons of STSC portal are very interesting. Students are very interested about the games. When I use games in English lessons, students interact largely and it motivates me lot. For this reason, I was searching more animated contents on English lessons and I found many contents with updated techniques on English lessons which enriched my knowledge and skill on ELT."

Table 3: STSC portal's effect size calculation

\section{Discussions}

\begin{tabular}{|c|c|c|c|c|c|c|c|}
\hline \multirow{3}{*}{$\begin{array}{l}\text { ELT } \\
\text { knowledge of } \\
\text { teachers }\end{array}$} & \multicolumn{2}{|c|}{ Pre-test } & \multicolumn{2}{|c|}{ Post-test } & \multirow{2}{*}{$\begin{array}{l}\text { Significance } \\
\text { at } 0.05 \text { level }\end{array}$} & \multirow{2}{*}{$\begin{array}{c}\text { Effect } \\
\text { size }\end{array}$} & \multirow{2}{*}{ Remarks } \\
\hline & $\mathrm{M}$ & SD & $\mathrm{M}$ & SD & & & \\
\hline & 1.93 & 0.813 & 2.64 & 0.731 & $\begin{array}{l}p=0.001 \\
\text { Very sig nificant }\end{array}$ & 0.91 & Very large \\
\hline
\end{tabular}

The result of the study clearly shows a significant improvement of the teachers' knowledge of effective English language teaching approaches for the classroom. The improvement

\section{Reasons behind the changes in English teachers' ELTK}

In the interviews, most of the English teachers responded that they got many teaching learning strategies related to ELT which motivated themselves and let them know about the ELT methodologies and practices. One of the teachers explained,

"I had no interest to know about the teaching learning strategies but when Dnet gave the CD (STSC portal) in our laptop, I just checked it out and seen that there are lots of things to know. I started to read sub-consciously and found interest. Then I also started to apply the strategies in my real class as a result now I know about few ELT concepts at least."

Some other teachers explained that interactive and animated contents helped them to make their class interactive and joyful which assist them to develop their pedagogical and technological knowledge and skills. A teacher added, occurred not only because of just providing the STSC portal, but also due to setting up the necessary devices and training on how to operate the portal and use the respective subject materials in the classrooms. One point is clear from this, providing materials alone cannot help to achieve the objectives of integrating ICT in education; effective training and other necessary arrangements are indispensable for getting the fruit of ICT.Most of the organizations who are working in the field of ICT in education basically emphasize on developing the multimedia contents and expect that the teachers will use them in their lessons. However, it should not be forgotten that how the contents will be incorporated in the lessons following the proper teachinglearning strategies. Besides the ICT skills, teacher's pedagogical skills for using the contents in their lessons in a proper way are also important. The STSC portal encompasses the materials which help the teacher to gain effective teaching-learning strategies as well as necessary pedagogical knowledge. Therefore, not only providing contents, but also how properly the contents can be brought into the classroom should be 
a major concern of the respective organizations and authorities.

In interviews, the teachers mentioned that the multimedia contents in the portal are interactive. However, the other materials, like, lesson plans, teaching-learning strategies, instructions on using ICT in classroom are mostly text based. The teachers suggested that these materials also can be converted into videos and other interactive formats, which may be more effective for them to grasp the inner meaning. Thus, development of interactive contents for teachers as well can be a consideration. Moreover, the materials the STSC portal has can be made available on the internet so that anyone gets access to these materials and use for the classroom.

\section{Conclusion}

The number of secondary school teachers of Bangladesh is huge and it is very difficult to develop all teachers' capacity on updated concept, content, technology and pedagogy through face-to-face training. In this situation, technology can be used for teachers' capacity development. The STSC portal shows a way how technology can be used for developing teachers' capacity. It may require modification and further development but policy makers as well as government and non-government organizations may think about the approach. The result of the study clearly depicts a positive change among teachers caused by the use of the STSC portal. The result can be more appropriate if it included a control group, select larger samples with proper distribution and observe real classroom practices. While conducting research studies in the same field, researchers may keep the mentioned issues in mind. For increasing the effectiveness of the STSC portal and making it more workable, Dnet should make the portal installation process simple so that teachers can easily re-install the portal into their PC if it uninstalled anyhow. However, the STSC portal presents an approach of combining all necessary materials for teachers in one platform and this study found the approach as very effective. More effective approaches can be developed and the initiatives can be scaled up throughout the country. For ensuring better quality in education, it was high time to take these kinds of initiative through incorporating ICT into education.

\section{About the authors}

S M Kamruddin Ropum is the Head of Innovations at Dnet and engaged in the development of innovative solutions for the marginalized people especially for the women and children in Bangladesh. He has extensive experience in educational research related to ICT, curriculum, materials, training, etc. and has several published articles.

Md. Yasin Arafat mainly works in the field of education. Currently, he is working for Save the Children in Bangladesh. He has widespread experience in integrating ICT in education for improving the education situation in Bangladesh. He has several articles published in different national and international research journals.

\section{References}

Aggarwal, J. C. (1993). Teaching of social studies: A practical approach. New Delhi: Vikas Publishing House Pvt. Ltd.

Ahmed, M., et al. (2005). Quality with equity: The primary eagenda. Dhaka: Campaign for Popular Education.

Cambridge ESOL (2007). Teaching knowledge test module 1, past examination paper. Retrieved October 25, 2013, from http:/ / www.cambridgeenglish.org/teachingenglish/teaching-qualifications/tkt/ 
Cambridge ESOL (2007). Teaching knowledge test module 1 , examination report. Retrieved October 25, 2013, from http:// www.cambridgeenglish.org/teachingenglish/teaching-qualifications/tkt/

Cambridge ESOL (2007). Teaching knowledge test module 2, past examination paper. Retrieved October 25, 2013, from http:/ / www.cambridgeenglish.org/teachingenglish/teaching-qualifications/tkt/

Cambridge ESOL (2007). Teaching knowledge test module 2, examination report. Retrieved October 25, 2013, from http:// www.cambridgeenglish.org/teachingenglish/teaching-qualifications/tkt/

Cambridge ESOL (2007). Teaching knowledge test module 3, past examination paper. Retrieved October 25, 2013, from http:/ / www.cambridgeenglish.org/teachingenglish/teaching-qualifications/tkt/

Cambridge ESOL (2007). Teaching knowledge test module 3, examination report. Retrieved October 25, 2013, from http:// www.cambridgeenglish.org/teachingenglish/teaching-qualifications/tkt/

Connolly, P. (2007). Quantitative data analysis in education. London and New York: Routledge.

Delors, J., et al. (1996). Learning: The treasure within. Report to UNESCO of the International Commission on Education for the Twenty-first Century.Paris: UNESCO

Dnet (2014). Who we are. Retrieved on February 2, 2014, from http:/ / www.dnet.org.bd

Fredriksson, U. (2004). Quality education: The key role of teachers. Education
International Working Papers no. 14, Retrieved December 20, 2014, from http://glotta.ntua.gr/posdep/ D i a 1 o g o s / Q u a 1 i t y / ei_workingpaper_14.pdf

Goodwin, A. L. (2008). Defining teacher quality: Is consensus possible?, In Cochran-Smith, M., Feiman-Nemser, S., McIntyre, D. J. and Demers, K. E. (Eds.), Handbook of research on teacher education: Enduring questions in changing contexts (pp.399-403). New York: Routledge.

Haq, N. (2006). Quality education needs quality teacher. Dhaka: Campaign for Popular Education.

Mackay, T. (2012, August 20). Teacher quality depends on culture of development. The Sydney Morning Herald. Retrieved February 10, 2014, from http://www.smh.com.au/ national/education/teacher-qualitydepends-on-culture-of-development20120819-24ghr.html

Mourshed, M., Chijioke, C, \& Barber, M. (2007). How the world's best-performing school systems come out on top. Retrieved January 15, 2014, from, http:// www.mckinsey.com/clientservice/ socialsector / resources / pdf / Worlds_School_Systems_Final.pdf

Mukti, A. (2002). Teacher empowerment and student achievement. Summary of Research Studies. Retrieved March 20, 2014, from http://my.opera.com/ muktibogor/blog/2011/07/10/ teacher-empowerment-and-studentachievement 
Mullick, J. I., \& Sheesh, S. (2008). Teachers' quality and teacher education at primary education sub-sector in Bangladesh. Brac University Journal, $\mathrm{V}(1), 77-84$.

Nunan, D. (1992). Research methods in language learning. New York: Cambridge University Press.

Prime Minister's Office (2013). Access to information (a2i) programme. Retrieved April 16, 2014, from http:// a2i.pmo.gov.bd/content/multimediaclass-room
Romanish, B. (1993). Teacher empowerment as the focus of school restructuring. The School Community Journal, 3(1), 47-60.

UNESCO (2014). Teaching and learning: Achieving quality for all. Education for All Global Monitoring Report. Retrieved April 14, 2014, from http:/ / unesdoc.unesco.org/images/0022/ 002256/225654e.pdf

World Education Forum (2000). The Dakar framework for action. Paris: UNESCO. 